\title{
DEMOKRASI DAN GERAKAN SOSIAL (BAGAIMANA GERAKAN MAHASISWA TERHADAP DINAMIKA PERUBAHAN SOSIAL)
}

\author{
Idil Akbar \\ Departemen Ilmu Pemerintahan, Fakultas Ilmu Sosial dan Ilmu Politik Universitas Padjadjaran \\ E-mail: idil.akbar@unpad.ac.id
}

\begin{abstract}
ABSTRAK
Lahirnya kelompok-kelompok sosial saat ini diyakini sebagai indikasi positif pertumbuhan dan pembangunan demokrasi di suatu negara, termasuk Indonesia. Kehadiran mereka bertujuan untuk terwujudnya perubahan sosial yang lebih baik dan memenuhi kepentingan rakyat. Salah satunya adalah gerakan mahasiswa yang di banyak peristiwa menjadi pionir bagi perubahan sosial. Artikel ini menganalisis bagaimana demokrasi menjadi faktor penting bagi gerakan sosial, khususnya gerakan mahasiswa terhadap terjadinya perubahan sosial di Indonesia. Penelitian ini menggunakan metode penelitian kualitatif deskriptif untuk menganalisis bagaimana gerakan sosial dan demokrasi di Indonesia, khususnya terkait dengan gerakan mahasiswa terhadap dinamika perubahan sosial. Diperoleh hasil, gerakan mahasiswa sebagai gerakan sosial merupakan faktor paling penting dalam mewujudkan perubahan sosial. Sebagai agen perubahan, idealisme mahasiswa menjadi nilai sejauhmana perubahan sosial tersebut berjalan dengan semestinya atau penuh dengan kepentingan. Gerakan mahasiswa ini pula menjadi penanda penting keberlangsungan demokrasi tetap berjalan.
\end{abstract}

Kata kunci: Gerakan sosial, Perubahan Sosial, Gerakan Mahasiswa, Demokrasi

\section{DEMOCRACY AND SOCIAL MOVEMENT: STUDENT MOVEMENT TOWARDS THE DYNAMICS OF SOCIAL CHANGE}

\begin{abstract}
Inception of social groups nowadays believed as positive indication cultivation of democracy in some country, including Indonesia. The existence of social group aims to create a social change better and gratify the people interest. One of social group is student movement that in any political event has become pioneer for social change. This article aims to analyze how is democracy become important factor to sosial movement, particularly student movement to occurance of social change in Indonesia. This research using qualitative descriptive method to analyze how is social movement and demoracy in Indonesia, especially related to student movement through to social change. As result that student movement is the most important thing to realizing social change. As agent of change, idealism of student is value indicator weather social change has moving as well or perhaps fulfill of political interest. The student movement also become indicator for sustainability of democracy.
\end{abstract}

Key words: Social movement, social change, students movement, democracy

\section{PENDAHULUAN}

Beberapa ilmuwan politik meyakini bahwa setelah perang dunia kedua, negara-negara bekas jajahan dan negara-negara berkembang mulai mencoba menjalankan demokratisasi. Hal ini terindikasikan dari salah satunya adalah diselenggarakannya pemilihan umum, sebagaimana yang terjadi di Indonesia tahun 1955. Meski baru dilakukan 10 tahun setelah kemerdekaan, setidaknya ini bisa menjadi salah satu tolak ukur bagi perkembangan demokrasi di Indonesia dan juga dinegara-negara berkembang lainnya. Perkembangan dan perjalanan negaranegara berkembang dideskripsikan oleh Samuel Huntington dalam bukunya The Third Wave of Democratization.

Dalam Tesisnya, Huntington ${ }^{1}$ menyebut tiga periode perkembangan demokrasi. Gelombang pertama, terjadi pada kurun waktu 1828-1926 (maksimal 33 negara), dimulai

${ }^{1}$ Samuel P. Huntington, Gelombang Demokratisasi Ketiga, Jakarta: PT Pustaka Utama Grafiti, 2001, hal. 13 
di Eropa dan dipicu oleh perkembangan di bidang sosial dan ekonomi. Kemajuan di bidang ekonomi, industrialisasi, urbanisasi, dan meningkatnya jumlah kelompok kelas menengah oleh Huntington dianggap sebagai penyebab utama tumbuhnya demokrasi di sejumlah negara Eropa saat itu.

Gelombang kedua terjadi pada kurun waktu 1943-1962 (maksimal 25 negara) dan penyebab utamanya adalah faktor politik dan militer. Menyusul kemenangan pihak Sekutu pada Perang Dunia Kedua, beberapa negara kemudian beralih ke demokrasi. Gelombang kedua ini berlanjut di sejumlah negara yang baru merdeka menyusul proses dekolonisasi.

Demokratisasi gelombang ketiga dimulai tahun 1974 (minimal 30 negara) dengan faktor penyebab yang lebih kompleks dibandingkan dua gelombang terdahulu. Empat di antaranya adalah melemahnya legitimasi rejim otoriter, perkembangan di sektor ekonomi, dampak dari proses serupa di kawasan (snowball effect), dan tekanan dari luar.Huntington memberi sebutan gelombang ketiga (third wave) untuk proses demokratisasi yang terjadi mulai pertengahan 1970-an sampai awal 1990-an. Dimulai dari Revolusi Mawar di Portugal sampai dengan perubahan politik di negara-negara eks Blok Timur menyusul usainya Perang Dingin.

Di Kawasan Asia, gelombang demokratisasi melanda ditandai dengan terbentuknya pemerintahan baru di India pada tahun 1977, Turki di tahun 1983 sebagai konsekuensi dari perebutan tahta pemerintahan yang dilakukan militer Turki pada tahun 1980, kemudian mengundurkan diri dan pemilihan umum berhasil membentuk pemerintahan sipil. Kemudian di Asia Tenggara Arus demokratisasi terasa di Filipina dengan tumbangnya rezim Marcos. Pada dasawarsa 80-an arus demokratisasi mengguncang dunia komunis, dimulai di Hoggaria pada 1988 dengan dimulainya proses menuju sistem multipartai, pada tahun 1989 beberapa pemimpin komunis di Uni Sovyet terkalahkan.

Dalam konteks lain, Huntington juga memberikan gambaran mengenai strategi bagi para pejuang demokrasi untuk melakukan proses reformasi sistem otoriter, beberapa strategi tersebut, antara lain: 1) Pejuang demokrasi haruslah mengamankan baris politik; 2) Mempertahankan legitimasi di belakang; 3) Memiliki strategi yang tepat untuk menghadapi kelompok yang konservatif; 4) Sedapat mungkin memegang kendali atas prakarsa politik; 5) Memberi dorongan bagi kelompok-kelompok oposisi yang memiliki keinginan kuat pada proses perubahan; 6) Menciptakan kesadaran bahwa demokrasi sebagai sebuah kemutlakan dalam mencapai keadaan yang lebih baik.

Disini Huntington melakukan telaah historis atas kondisi politik dalam negeri di beberapa negara, terutama di Asia, Amerika dan Afrika. Ia menangkap bahwa proses demokratisasi yang bermula pada tahun 1828 dan memasuki fase ketiga pada tahun 1974 hingga sekarang. Ia melihat proses ini sebagai bentuk arus demokratisasi yang melanda dunia secara luas dan mengakibatkan berjatuhannya rezim pemerintahan otoriter dan digantikan rezim yang demokratis.

Salah satu dinamika penting dari demokratisasi yang berlangsung di negara-negara dunia ketiga, termasuk Indonesia adalah lahirnya kelompok-kelompok sosial masyarakat yang menunjukkan perhatian dan kepedulian tentang kondisi di dalam upaya menuju tercapainya masyarakat yang demokratis. Mereka membangun kesadaran bersama dan bergerak bersama, melibatkan diri dalam persoalan dan menentukan arah dari kebijakan negara. Kelompok-kelompok ini bergerak untuk menjaga agar proses demokratisasi berjalan dengan baik. Mereka adalah kelompok masyarakat yang terintegrasi di dalam sebuah gerakan sosial.

Fenomena gerakan sosial dewasa ini cukup dinamis, terlihat dari kemunculan mereka yang, baik sudah terlembaga dengan baik maupun yang bersifat sporadis serta kasusistik. Namun, terpenting adalah bahwa gerakan sosial membawa misi tertentu, yakni adanya perubahan di dalam masyarakat yang lebih baik dan tentunya demokratis. Tak jarang, mereka justru menjadi pionir bagi perubahan yang bersifat radikal dan fundamental. Mereka berjalan dalam sebuah tuntutan perubahan terhadap kondisi yang dinilai buruk dan sewenang-wenang. Salah satu gerakan sosial yang paling dikenal adalah gerakan mahasiswa. Mereka menjadi bagian penting di dalam mengkerangkai tatanan sosial politik di banyak negara, termasuk Indonesia. Reformasi yang terjadi pada 1998 merupakan buah karya dari gerakan mahasiswa yang menginginkan terjadinya demokratisasi secara benar dan menyingkirkan rezim otoritarian yang 
sudah berjalan cukup lama. Mereka inilah yang sejatinya dikatakan oleh huntington sebagai pejuang demokrasi dan menjaga pakem dari demokratisasi tetap berlangsung.

Dalam konteks demokrasi seperti ini dan dampaknya terhadap gerakan social khususnya gerakan mahasiswa di Indonesia, penting menjawab pertanyaan penting, yakni pertama, mengapagerakan mahasiswamenjadipenting dan berpengaruh di dalam gelombang Demokratisasi ketiga? Kedua, bagaimana gerakan mahasiswa menjadi pionir bagi terjadinya perubahan sosial di dalam kerangka Demokratisasi ketiga?

\section{Pembangunan Demokrasi}

Wacana mengenai demokrasi sangat kencang di abad 20-an. Akar dari gagasan demokrasi telah tumbuh sejak jaman Yunani Kuno. Hanya saja prinsip-prinsipnya mulai benar-benar dianut setelah Barat mengganggap sistem monarki absolut tidak sesuai dengan masyarakat. Ada banyak pengertian mengenai demokrasi. Menurut Miriam Budiarjo, demokrasi mempunyai asal kata berarti "rakyat berkuasa" atau "goverment or rule by the people". (Kata Yunani demos berarti rakyat, kratos/ kratein berarti kekuasaan/berkuasa).

Sesudah Perang Dunia II kita melihat gejala bahwa secara formil demokrasi merupakan dasar dari kebanyakan negara di dunia. Menurut suatu penelitian yang diselenggarakan oleh UNESCO dalam tahun 1949 maka "mungkin untuk pertama kali dalam sejarah demokrasi dinyatakan sebagai nama yang paling baik dan wajar untuk semua sistim organisasi politik dan sosial yang diperjuangkan oleh pendukung-pendukung yang berpengaruh"'.

Sebagaimana diketahui, akar-akar demokrasi telah muncul ketika jaman Yunani Kuno. Gagasan demokrasi yang berpengaruh juga banyak muncul di abad ke 17-19, dimana ini banyak digolongkan dengan pemikiran demokrasi klasik. Seperti pemikiran John Locke bahwa setiap individu harus menyesuaikan diri dengan kehendak mayoritas. Setiap individu meyumbangkan jumlah kekuatan fisik yang sama, oleh karena itu setiap keputusan yang disetujui oleh jumlah individu yang lebih banyak harus diterima sebagai keputusan yang mengikat. Dari pandangan itu dapat disimpulkan

\footnotetext{
${ }^{2}$ Miriam Budiarjo, 2002, Dasar-Dasar Ilmu Politik, Jakarta : PT Gramedia Pustaka Utama, hlm 50
}

bahwa Locke membenarkan tirani mayoritas sebab tindakan mayoritas bisa saja melanggar hak-hak individu kalangan minoritas.

Tetapi untuk melindungi hak-hak minoritas dan hak individu dari tirani kekuasaan yang absolut dan sembarangan, pemerintah harus melaksanakan kewenangannya berdasarkan hukum. Hanya saja pejabat negara tidak hanya bertindak sesuai hukum, tetapi pembuat hukum (legislatif) harus terpisah dari pelaksana hukum (eksekutif) dan pengadilan (judikatif). Pemerintahan berdasarkan hukum dan pemisahan kekuasaan, menurut Locke dapat mengendalikan sifat mementingkan diri sendiri dan melayani kepentingan sendiri dari orang yang berwenang. Atas dasar itu, Locke mengemukakan empat syarat bagi kewenangan legislatif, yakni menetapkan suatu hukum bagi semua orang, membuat hukum yang hanya bertujuan bagi kebaikan warga masyarakat, tidak mengenakan atau menaikkan pajak tanpa persetujuan warga masyarakat, dan tidak mengalihkan kewenangan membuat hukum kepada lembaga yang lain ${ }^{3}$.

Di akhir abad ke-19 dan awal abad ke20 muncul berbagai pandangan demokrasi yang dibentuk oleh kepekaan dampak segisegi negatif dari hidup di peradaban teknologi maju. Selain itu juga berpandangan terhadap akibat-akibat yang tidak dapat diramalkan dari tindakan politik yang paling baik sekalipun. Oleh karena itu dalam pembahasan lebih lanjut gagasan kedaulatan rakyat berfokus pada pemikiran Max Weber (1864-1929) dan Josep Schumpeter (1883-1950). Mereka memiliki gagasan yang sama terhadap kehidupan politik dimana untuk berperan serta dalam demokrasi dan perkembangan individual atau kolektif kecil dan andaikata ada kesempatan pun maka akan selalu terancam oleh kekuatan sosial yang besar. Keduanya masih percaya bahwa demokrasi merupakan sistem terbaik dalam negara namun mereka beranggapan bahwa demokrasi hanya sebatas cara memilih para pengambil keputusan dan menyingkirkan sisanya ${ }^{4}$.

Lebih lanjut menurut Schumpeter kemunculan demokraasi tidak dapat lepas dari system

\footnotetext{
${ }^{3}$ Lee Cameron McDonald, 1968, Western Political Theory, Jilid II, New York: Harcourt Brace Javanovich, hlm 333

${ }^{4}$ David Held, 2006, Models of Democracy (terj), Jakarta: The Akbar Tandjung Institute, hlm 143
} 
ekonomi kapitalis. Peran rakyat dalam suatu masyarakat demokratis bukan untuk memerintah atau bahkan menjalankan keutusan-keputusan umum masalah politik. Rakyat hanya memilih orang-orang yang akan membuat keputusan mereka. Jadi secara sederhana, demokrasi menurut Schumpeter adalah suatu mekanisme untuk pemilihan dan memberi kekuasaan pada pemerintah, mekanisme tersebut merupakan suatu kompetisi antara satu atau lebih kelompok para kompetisi yang terpilih dimana dipilih melalui partai politik ${ }^{5}$ Pengertian ini juga ditegaskan pada gagasan Giovani Sartori. Sartori menyatakan bahwa demokrasi adalah suatu system politik dimana pengaruh kelompok mayoritas dijamin oleh kelompok minoritas yang dipilih dan berkompetisi dan kepadanyalah sistem itu dipercayakan ${ }^{6}$. Inilah yang dimaksud dengan demokrsi elitis.

Pandangan ini ingin diubah oleh John Dewey yang masih percaya adanya demokrasi elitis bisa berubah menjadi demokrasi partisipasi. Demokrasi partisipasi memerlukan: (1) perubahan kesadaran masyarakat yang tadinya memandang diri mereka sebagai penerima pasif segala bentuk kekuasaan menjadi aktif dalam partisipasi positif dalam proses pengambilan keputusan oleh negara, (2) pengurangan secara besar-besar segala ketimpangan yang $\mathrm{ada}^{7}$.

Secara garis besar, untuk mengukur tingkat demokrasi ada beberapa indikator yang daat digunakan. Robert Dahl mengemukakan indikator tersebut : (1) Akuntabilitas, (2) Rotasi kekuasaan, (3) Rekruitmen politik yang terbuka, (4) Pemilihan Umum, (5) Menikmati hak-hak dasar ${ }^{8}$.

Pelaksanaan demokrasi di Indonesia telah mengalami perjalanan yang cukup panjang. Dari masa ke masa demokrasi dimaknai dengan cara yang berbeda-beda. Pemaknaan yang berbeda pada tiap masa dipengaruhi oleh berbagai kondisi yang dihadapi saat itu. Dari berbagai macam pemaknaan dan pelaksanaannya, demokrasi di Indonesia dapat dikatakan belum betulbetul terlaksana dengan baik. Hal ini bisa dilihat dari berbagai permasalahan yang dialami dalam pelaksanaan demokrasi dari masa awal kemer-

\footnotetext{
${ }^{5}$ SP Varma, 2007, Teori Politik Modern, PT. Raja Grafindo Persada, hlm 211

6 Ibid, hlm 214

${ }^{7}$ Ibid, hlm 223

${ }^{8}$ Indikator ini disimpulkan oleh Afan Gafar, 1999, Politik Indonesia: Transisi Menuju Demokrasi, Pustaka Pelajar, hlm 7-9
}

dekaan sampai era reformasi saat ini.

Berbagai permasalahan yang terjadi seringkali memunculkan pertanyaan, demokrasi seperti apakah yang sebenarnya ideal untuk dilaksanakan di Indonesia? Setiap negara/ bangsa mempunyai budaya yang berbeda antara satu dengan lainnya. Pemahaman demokrasi menjadi kabur apabila tidak ada tolak ukur yang pasti, dan mengikuti semua nilai yang ada dalam sebuah budaya di suatu negara/bangsa. Tolak ukur (prasyarat) ataupun kriteria dalam melihat perkembangan demokrasi merupakan nilai-nilai universal yang terdapat di semua budaya dalam suatu negara dan dapat dilihat dari lembaga-lembaga negara yang ada. Lima kriteria seperti yang telah kami paparkan pada awal makalah, merupakan nilai dasar demokrasi yang bersifat universal dimana tidak satupun negara/bangsa yang dapat mengklaim sebagai pemiliknya. Setiap negara memiliki unsur-unsur di dalam sejarah dan budayanya sebagai nilainilai demokrasi. Bisa dikatakan, lima kriteria ini memang prasyarat minimal dalam menen-tukan sebuah negara itu demokratis atau tidak. Dan dalam kriteria berikutnya, seharusnya menyesuaikan pada kondisi objektif dari masingmasing negara yang dalam hal ini adalah nilainilai budayanya.

Apa yang terjadi saat itu terasa masih tetap relevan dan bisa dikatakan kelanjutan dari gelombang ketiganya Huntington. Contohnya adalah proses demokratisasi di Indonesia. Dilihat dari faktor penyebabnya demokratisasi di Indonesia bermula dari melemahnya legitimasi rejim otoriter yang berkuasa mulai awal 1990an. Perkembangan di sektor ekonomi, yaitu kegagalan mengatasi krisis ekonomi tahun 1997, menjadi puncak dari perlemahan legitimasi tersebut.Faktor tekanan dari luar terlihat tidak begitu dominan. Namun dengan berkurangnya kepentingan negara adikuasa di Indonesia setelah runtuhnya blok komunis, bagi negaranegara maju mendukung rejim otoriter tidak lagi menjadi pilihan populer. Sistem politik global tidak lagi berpihak kepada rejim Orde Baru yang berkuasa saat itu.

Pandangan konsep demokrasi Huntington disini merujuk pada konsep yang dibuat para filsuf Yunani dalam terminologi klasik demokrasi diisentikan dengan kehendak rakyat (the will of the people) sebagai sumber atau legitimasi demokrasi dan kebaikan bersama (the 
common good) sebagai tujuan. Berbeda dengan Schumpeter yang mencoba mematahkan teori demokrasiklasik itu dengan the another theory of democracy. Schumpeter mendefinisikan demokrasi lebih sebagai sebuah proses. Demokrasi ia definisikan sebagai prosedur kelembagaan untuk mencapai keputusan politik yang di dalamnya individu memperoleh kekuasaan untuk membuat keputusan melalui perjuangan kompetitif dalam rangka memperoleh suara rakyat.

Ini menegaskan bahwa demokrasi menurut Huntington tidak bersifat kaku atau fleksibel. Namun yang tidak disinggung Huntington mengenai wajah baru otoritarian dengan wajah demokrasi. Ini yang menjadi salah satu kelemahan analisa Huntington. Analisa lebih banyak fokus ke bentuk pemerintahan sehingga teori demokratisasi gelombang ketiga kurang relevan menjadi pisau analisa demokrasi dan pembangunan ekonomi. Berbeda dengan Barington Moore (The Social Origins of Dictatorship and Democracy, 1996) yang dengan jelas tesisnya menunjuk demokrasi berkaitan dengan ekonomi. Tesinya yang terkenal yaitu No bourgoise, no democracy'.

\section{Gerakan Sosial}

Dewasa ini, gerakan sosial (social movement) menjadi pokok bahasan yang popular bagi kalangan sosiolog di Barat, khususnya di Amerika Serikat. Studi yang telah dilakukan mengenai gerakan hak-hak sipil di kalangan Kulit Hitam di Amerika Serikat tahun 1950an dan 1960an, serta kajian mengenai berbagai gerakan, seperti gerakan mahasiswa tahun 1960an dan 1970an, gerakan lingkungan hidup, gerakan perdamaian dan gerakan solidaritas maupun gerakan perempuan pada tahun 1970an dan 1980an, kesemuanya membawa akibat lahirnya bermacam-macam pendekatan dan teori tentang gerakan sosial $^{10}$.

Beberapa gerakan sosial yang sering dipilih untuk dijadikan bahan studi atau kajian antara lain Gerakan Perjuangan Etnis atau Nasionalis di negara-negara bagian (bekas) Uni Soviet, Gerakan Anti Aparheid di Afrika Selatan dan Gerakan Sosial di Negara Dunia Ketiga, baik perjuangan untuk tujuan peningkatan kondisi hidup maupun terkait pemerataan distribusi

\footnotetext{
${ }^{9}$ Huntington, ibid, hal. 23.

${ }_{10}$ Mansour Fakih, Masyarakat Sipil untuk Transformasi Sosial, Pustaka Pelajar, 1966, hal. 35.
}

sumber daya ekonomi. Khusus untuk gerakan sosial yang ada di Negara Dunia Ketiga, seringkali berkaitan secara tidak langsung dengan pendekatan perubahan sosial yang dominan (mainstream approach), yaitu suatu perubahan sosial yang direkayasa oleh Negara, melalui apa yang disebut sebagai Pembangunan (Development). Pembangunan seringkali dianggap oleh masyarakat sebagai penyebab kemacetan ekonomi, krisis ekologis, serta berbagai kesengsaraan masyarakat di Negara Dunia Ketiga. Dan hal tersebut merupakan perlawanan dan kritik terhadap skenarioModernisasi, yang mengasumsikan dan merancang untuk membawa kemajuan dan kemakmuran masyarakat di suatu Negara Dunia Ketiga. Menurut pendapat Bonner, dalam konteks Dunia Ketiga, studi tentang gerakan sosial dan transformasi sosial tidak dapat dipisahkan dari masalah "Pembangunan".

Studi tentang gerakan sosial dapat dibagi menjadi dua pendekatan yang saling bertentangan ${ }^{11}$. Pendekatan pertama adalah teori yang cenderung melihat gerakan sosial sebagai suatu "masalah" atau disebut sebagai gejala penyakit masalah kemasyarakatan. Teori ini berakar dan dipengaruhi oleh teori sosiologi dominan, yaitu Fungsionalisme atau sering disebut sebagai Fungsionalisme Struktural. Fungsionalisme melihat masyarakat dan pranata sosial sebagai sistem dimana seluruh bagiannya saling tergantung satu sama lain dan bekerja bersama guna menciptakan keseimbangan. Dalam hal ini "keseimbangan" merupakan unsur kunci utama dengan menekankan pentingnya kesatuan masyarakat dan sesuatu yang dimiliki bersama oleh anggotanya. Oleh sebab itu, gerakan sosial dianggap sebagai sesuatu yang "negatif" karena akan dapat menimbulkan konflik yang dapat mengganggu keharmonisan dalam masyarakat.

Pendekatan kedua adalah teori-teori ilmu sosial yang justru melihat gerakan sosial sebagai "fenomena positif", atau sebagai sarana konstruktif bagi perubahan sosial. Pendekatan ini merupakan alternatif terhadap fungsionalisme, dan dikenal dengan "Teori Konflik". Teori konflik pada dasarnya mengunakan tiga asumsi dasar, yaitu: 1) Rakyat dianggap sebagai sejumlah kepentingan dasar dimana mereka akan berusaha secara keras untuk memenuhinya, 2) Kekuasaan adalah inti dari struktur sosial dan hal ini

${ }^{11}$ Mansour Fakih, ibid, hal. 36 
melahirkan perjuangan untuk mendapatkannya, dan 3) Nilai dan gagasan adalah senjata konflik yang digunakan oleh berbagai kelompok untuk mencapai tujuan masing-masing, dari pada sebagai alat mempertahanlan identitas dan menyatukan tujuan masyarakat.

Generasi Marxisme baru (dipengaruhi oleh pemikiran Antonio Gramsci: 1891-1937) menyatakan bahwa peran manusia sebagai agen, termasuk ideologi, kesadaran kritis dan pendidikan, dalam mentransformasikan krisis ekonomi menjadi krisis umum. Mereka menolak bahwa perekonomian adalah sesuatu yang esensial dan faktor penentu bagi perubahan sosial, serta menolak gagasan determinisme historis yang mengagungkan manusia sebagai faktor penting di antara banyak faktor lainnya yang saling tergantung secara dialektis. Mereka mengajukan argumen bahwa gerakan sosial yang terjadi pada tahun 1970an dan 1980an sama sekali tidak menekankan ke arah gerakan perjuangan kelas, seperti yang didefinisikan oleh penganut Marxisme tradisional. Gerakan spiritual, gerakan fenimisme, gerakan hak azasi manusia dan hak-hak sipil, gerakan anti perang dan anti nuklir, gerakan sosial berbasis komunitas dan gerakan pecinta lingkungan, serta gerakan Lembaga Swadaya Masyarakat merupakan gerakan yang tidak berkaitan secara langsung dengan perjuangan kelas dari kelas buruh.

Antonio Gramsci adalah pemikir politik yang sangat mempengaruhi pendekatan kedua ini, yaitu dengan teorinya tentang perubahan sosial yang nonreduksionis dan teorinya mengenai hegemoni. Implikasi teori hegemoni adalah bahwa kelas buruh tidak lagi dianggap sebagai pusat gerakan revolusioner atau bukan lagi titik fokal dan sebagai unsur utama dalam gerakan perubahan sosial. Disamping itu Gramsci juga mengemukakan teorinya tentang kemungkinan menciptakan aliansi antara unsur kelas buruh dan kelompok lainnya, dan menekankan transformasi kesadaran sebagai bagian proses revolusioner.

\section{METODE}

Penelitian ini dilaksanakan melalui kajian literatur dengan pendekatan deskriptif kualitatif untuk menganalisis bagaimana demokrasi memberi ruang penting bagi tumbuhkembang gerakan sosial, khususnya gerakan mahasiswa, sehingga bisa memberikan sentuhan penting bagi perubahan sosial di Indonesia. Penelitian deskriptif bertujuan untuk menjelaskan suatu peristiwa yang operasionalisasinya berkisar pada pengumpulan data, pengolahan data dan penafsiran data yang diberi makna secara rasional dengan tetap memegang prinsip-prinsip logika sehingga terbentuk kesimpulan yang holistik. Tujuan lain dari penelitian deskriptif adalah untuk membuat deskripsi, gambaran atau lukisan, faktual dan akurat mengenai faktafakta, sifat-sifat serta hubungan antarfenomena yang diselidiki. Sedangkan penelitian eksploratif bersifat terbuka bertujuan untuk membangun suatu teori setelah melalui pengamatan empiris.

\section{HASIL DAN PEMBAHASAN}

\section{Gerakan Mahasiswa di Negara Berkembang}

Mahasiswa merupakan komponen masyarakat kelas menengah. Yang membedakan mereka dengan masyarakat awam adalah mereka mereka adalah kelompok masyarakat berpendidikan dan sehari-harinya bergelut dengan pencarian kebenaran dalam kampus melihat kenyataan yang berbeda dalam kehidupan nasionalnya. Kegelisahan kalangan mahasiswa ini kemudian teraktualisasikan dalam aksi-aksi protes yang kemudian mendorong perubahan yang reformatif dalam sistem politik di Indonesia.

Edward Shill mengkategorikan mahasiswa sebagai lapisan intelektual yang memliki tanggung jawab sosial yang khas. Shill menyebukan ada lima fungsi kaum intelektual yakni mencipta dan menyebar kebudayaan tinggi, menyediakan bagan-bagan nasional dan antar bangsa, membina keberdayaan dan bersama, mempengaruhiperubahan sosial dan memainkan peran politik. Arbi Sanitmemandang, mahasiswa cenderung terlibat dalam tiga fungsi terakhir. Sementara itu Samuel Huntington menyebutkan bahwa kaum intelektual di perkotaan merupakan bagian yang mendorong perubahan politik yang disebut reformasi.

Menurut Arbi Sanit ada empat faktor pendorong bagi peningkatan peranan mahasiswa dalam kehidupan politik ${ }^{12}$. Pertama, sebagai kelompok masyarakatyang memperoleh pendidikan terbaik, mahasiswa mempunyai horison yang luas diantara masyarakat. Kedua, sebagai_kelompok masyarakat yang paling ${ }^{12}$ Arbi Sanit, Sistim Politik Indonesia, Jakarta, Penerbit CV Rajawali, 1981, hal.107-110 
lama menduduki bangku sekolah, sampai di universitas mahasiswa telah mengalami proses sosialisasi politik yang terpanjang diantara angkatan muda. Ketiga, kehidupan kampus membentuk gaya hidup yang unik di kalangan mahasiswa. Di Universitas, mahasiswa yang berasal dari berbagai daerah, suku, bahasa dan agama terjalin dalam kegiatan kampus seharihari. Keempat, mahasiswa sebagai kelompok yang akan memasuki lapisan atas dari susunan kekuasaan, struktur perekonomian dan prestise dalam masyarakat dengan sendirinya merupakan elit di dalam kalangan angkatan muda.

Gerakan mahasiswa merupakan bagian dari gerakan sosial yang didefinisikan Nan Lin ${ }^{13}$ sebagai upaya kolektif untuk memajukan atau melawan perubahan dalam sebuah masyarakat atau kelompok. Rudolf Heberle ${ }^{14}$ menyebutkan bahwa gerakan sosial merujuk pada berbagai ragam usaha kolektif untuk mengadakan perubahan tertentu pada lembaga-lembaga sosial atau menciptakan orde baru. Bahkan Eric Hoffer menilai bahwa gerakan sosial bertujuan untuk mengadakan perubahan. Teori awal menyebutkan, sebuah gerakan muncul ketika masyarakat menghadapi hambatan struktural karena perubahan sosial yang cepat seperti disebutkan Smelser (1962). Teori kemacetan ini berpendapat bahwa "pengaturan lagi struktural dalam masyarakat seperti urbanisasi dan industrialisasi menyebabkan hilangnya kontrol sosial dan meningkatkan "gelombang menuju perilaku antisosial". Kemacetan sistemik ini dikatakan menjadi penyebab meningkatnya aksi mogok, kekerasan kolektif dan gerakan sosial dan mahasiswa Pakar kontemporer tentang gerakan sosial mengkritik teori-teori kemacetan dengan alasan empirik dan teoritis.

Denny JA juga menyatakan adanya tiga kondisi lahirnya gerakan sosial seperti gerakan mahasiswa ${ }^{15}$. Pertama, gerakan sosial dilahirkan oleh kondisi yang memberikan kesempatan bagi gerakan itu. Pemerintahan yang moderat, misalnya memberikan kesempatan yang lebih besar bagi timbulnya gerakan sosial ketimbang pemerintahan yang sangat otoriter. Kedua, gerakan sosial timbul karena meluasnya ketidakpuasan atas situasi yang

\footnotetext{
${ }^{13}$ Nan Lin, Social Movement dalam Encyclopedia of Sociology, New York: MacMillan Publishing Company, 1992, hal. 1880.

${ }^{14}$ Dikutip dari Asep Setiawan dalam Diktat Gerakan Sosial, Jakarta: Jurusan Ilmu Politik, FISIP UMJ, 1998， hal.10.

${ }^{15}$ Denny JA, Menjelaskan Gerakan Mahasiswa, Harian Kompas, 25 April 1998, diambil dari www.kompas.com, tanggal 5 Mei 2010, jam 14.00 wib.
}

ada. Perubahan dari masyarakat tradisional ke masyarakat modern, misalnya dapat mengakibatkan kesenjangan ekonomi yang makin lebar untuk sementara antara yang kaya dan yang miskin. Perubahan ini dapat pula menyebabkan krisis identitas dan lunturnya nilai-nilai sosial yang selama ini diagungkan. Perubahan ini akan menimbulkan gejolak yang dirugikan dan kemudian meluasnya gerakan sosial. Ketiga, gerakan sosial sematamasa masalah kemampuan kepemimpinan dari tokoh penggerak. Adalah sang tokoh penggerak yang mampu memberikan inspirasi, membuat jaringan, membangun organisasi yang menyebabkan sekelompok orang termotivasi terlibat dalam gerakan.Gerakan mahasiswa mengaktualisikan potensinya melalui sikap-sikap dan pernyataan yang bersifat imbauan moral. Mereka mendorong perubahan dengan mengetengahkan isu-isu moral sesuai sifatnya yang bersifat ideal. Ciri khas gerakan mahasiswa ini adalah mengaktualisasikan nilai-nilai ideal mereka karena ketidakpuasan terhadap lingkungan sekitarnya.

Gerakan moral ini diakui pula oleh Arief Budiman yang menilai sebenarnya sikap moral mahasiswa lahir dari karakteristiknya mereka sendiri. Mahasiswa, tulis Arief Budiman, sering menekankan peranannya sebagai "kekuatan moral" dan bukannya "kekuatan politik"16. Aksi protes yang dialncarkan mahasiswa berupa demonstrasi di jalan dinilai juga sebagai sebuah kekuatan moral karena mahasiswa bertindak tidak seperti organisasi sosial politik yang memiliki kepentingan praktis. Sependapat dengan Arief Budiman, Arbi Sanit menyatakan komitmen mahasiswa yang masih murni terhadap moral berdasarkan pergulatan keseharian mereka dalam mencari dan menemukan kebenaran lewat ilmu pengetahuan yang digeluti adalah sadar politik mahasiswa. Karena itu politik mahasiswa digolongkan sebagai kekuatan moral ${ }^{17}$. Kemurnian sikap dan tingkah laku mahasiswa menyebabkan mereka dikategorikan sebagai kekuatan moral, yang dengan sendirinya memerankan politik moral.

Peran mahasiswa sebagai gerakan moral dan gerakan massa untuk mendorong reformasi politik adalah bagian dari tanggung jawabnya

\footnotetext{
${ }^{16}$ Arief Budiman, Peranan Mahasiswa sebagai Inteligensia dalam Cendekiawan dan Politik, Jakarta, LP3ES, 1984, hal.160.

17 Arbi Sanit, Reformasi Politik, Yogyakarta, Pustaka Pelajar, 1998, hal.267
} 
sebagai kaum intelektual. Berbeda dengan gerakan revolusi, gerakan reformasi seperti dikatakan, Nanlin, berbeda dengan gerakan revolusi yang mengejar perubahan struktural yang fundamental. Gerakan reformasi berusaha memodifikasi hubungan struktural tanpa mengancam eksistensi insitusi. Menurut Arbi ada dua tahap dalam reformasi politik. Pertama, tahap transisi yang merupakan proses peralihan dari proses krisis politik ke proses normal kehidupan politik $^{18}$.

\section{Gerakan Mahasiswa: Dimensi Perubahan Sosial}

Di Negara dunia ketiga seperti Indonesia, status mahasiswa dan gerakannya sangat penting sebagai salah satuagent of change, karenatekanan politik ekstra parlementer merupakan salah satu mekanisme efektif untuk dapat mengontrol penguasa. Namun gerakan mahasiswa tidak bisa dipungkiri merupakan bukan merupakan elemen satu-satunya yang dapat mewujudkan perubahan dalam masyarakat, terkadang gerakan mahasiswa hanya mampu sebatas menjadi pendobrak dari kevakuman perlawanan yang ada terhadap penguasa. Setelah penguasa yang didobrak turun, maka gerakan mahasiswa akan menyerahkan kelanjutan proses tersebut kepada elemen masyarakat lain untuk melanjutkan. Karena memang gerakan mahasiswa dilandasi atas perjuangan moral meskipun wilayah perlawanannya berada pada wilayah politik. Moralitas inilah yang kemudian dapat mencapai reformasi di Indonesia. Dengan cita-cita reformasi, gerakan mahasiswa memberikan andil yang luar biasa agar tercapai harapan masyarakat yang demokratis.

Gerakan mahasiswa dewasa ini manghadapi dua tantangan besar dalam mewujudkan perannya ${ }^{19}$. Pertama, menghadapi implikasi dari proses globalisasi ekonomi, politik dan budaya yang berasal dari Negara-negara industri maju. Kedua, tantangan yang menyangkut proses demokratisasi, dari segi ekonomi, politik dan sosio-kultural. Guna menghadapi tantangan kedua ini, maka gerakan mahasiswa perlu untuk menciptakan cita-cita bersama bangsa yang menjadi landasan pergerakan. Cita-cita bersama ini harus sederhana namun dapat merangkul semua kepntingan rakyat.

\footnotetext{
18 Arbi Sanit, ibid, hal, 129

19 Ahmad Nasir Siregar, Mahasiswa dan Perubahan Sosial (makalah), http://hmi.or.id/berita/44/mahasiswa-dan-perubahan-sosial, diunduh tanggal 5 Mei 2010, jam 11.00 wib.
}

Selain itu, gerakan mahasiswa harus mampu pula menciptakan metode aksi yang merupakan kombinasi dari aksi massa dan aksi intelektual, orientasi gerakan tidak hanya tertuju pada struktur kekuasaan yang bermasalah, tetapi juga dditambah dengan pembentukan opini politik ditengah masyarakat luas sebagai aksi informasi dan penyadaran public. Gerakan mahasiswa tidak boleh terlepas dari akarnya, yaitu rakyat.

Mahasiswa juga perlu membina kekuatan dan jaringan yang terorganisir. Gerakan mahasiswa tidak boleh terpisah-pisah dalam kerangkeng ideologi masing-masing organisasi atau kelompok, harus ada satu kesatuan yang utuh terikat dalam satu tujuan untuk membela rakyat. Karena dengan kekuatan yang terpencar akan memudahkan rezim mematahkan gerakan mahasiswa. Selain itu gerakan mahasiswa harus mampu berkoordinasi dengan kekuatan pergerakan lain seperti gerakan buruh, petani, nelayan, keagamaan, perkumpulan profesi dll, demi menyusun barisan oposisi ekstra parlementer yang akan melawan rezim. Dengan perlawanan yang terorganisir maka setiap potensi kekuatan yang ada dapat dimanfaatkan serta diberdayagunakan untuk mewujudkan perubahan social yang di kehendaki bersama.

Karena itu, dalam perspektif Gramscian, konsep organisasi gerakan mahasiswa bisa dikategorikan pula sebagai masyarakat sipil terorganisir. Konsep tersebut didasarkan pada analisis tentang kepentingan konfliktual dan dealektika atau kesatuan dalam keberbedaan antara Negara (State) dengan Masyarakat Sipil (Civil Society). Masyarakat sipil terdiri dari berbagai bentuk masyarakat voluntir dan merupakan dunia politik utama, dimana semuanya berada dalam aktivitas ideology dan intektual yang dinamis maupun konstruksi hegemoni. Masyarakat sipil merupakan konteks dimana seseorang menjadi sadar dan seseorang pertama kali ikut serta dalam aksi politik. Dengan demikian, masyarakat sipil adalah suatu agregasi atau percampuran kepentingan, dimana kepentingan sempit ditransformasikan menjadi pandangan yang lebih universal sebagai ideologi dan dipakai atau diubah. Dalam konteks ini, bagi Gramsci masyarakat sipil adalah dunia dimana rakyat membuat perubahan dan menciptakan sejarah ${ }^{20}$. Menurut pernyataan

${ }^{20}$ Mansour Fakih, po.cit, hal. 41. 
Gramsci "semua orang adalah intelektual, maka seseorang dapat mengatakannya demi-kian; tetapi tidak semua orang memiliki fungsi intelektual dalam masyarakat”.

\section{SIMPULAN}

Fenomena gerakan mahasiswa menjadi fenomena tersendiri di dalam upaya melaksanakan demokratisasi di Indonesia, bahkan menjadi salah satu tolak ukur penting di dalam keberhasilan bagi perjalanan menuju negara yang demokratis. Pengupayaan bagi koeksistensi gerakan mahasiswa sebetulnya akan mampu menyediakan kondisi yang lumrah di dalam mencapai konsolidasi demokrasi. Dengan syarat, mereka tetap dijadikan komponen yang tak terpisahkan di dalam mengkerangkai arah dan orientasi dari sistem pemerintahan yang dijalankan.

Sebagai sebuah gerakan sosial, tentunya gerakan mahasiswa dituntut untuk tetap konsisten di dalam menjalankan idealisme utama yakni mendudukkan kepentingan masyarakat luas, terutama di dalam menghadapi kebijakan negara yang kadang cenderung tak berpihak. Gerakan mahasiswa adalah pejuang demokrasi yang tentunya mesti senantiasa berjuang menegakkan prinsip-prinsip dan nilai-nilai yang ada di dalam demokrasi. Disinilah pentingnya gerakan mahasiswa ini, yakni selain sebagai prasyarat bagi proses demokratisasi yang berlangsung, tetapi juga sebagai penyeimbang di dalam mekanisme sistem pemerintahan.

Momentum gerakan mahasiswa tentu tak akan pudar selama demokratisasi masih terus berlangsung. Sebab, bagi kawan-kawan mahasiswa, selama masih terjadi ketimpangan dan ketidakadilan di dalam menjalankan nilai-nilai demokrasi, maka selama itu pula perjuangan akan tetap dilakukan.

\section{DAFTAR PUSTAKA}

Asep Setiawan, Asep (diktat), Gerakan Sosial, Jurusan Ilmu Politik, FISIP UMJ, Jakarta, 1998.
Budiarjo, Miriam, Dasar-Dasar Ilmu Politik, Gramedia Pustaka Utama, Jakarta, 2002.

Budiman, Arif, Peranan Mahasiswa sebagai Inteligensia dalam Cendekiawan dan Politik, Jakarta, LP3ES, 1984.

Fakih, Mansour, Masyarakat Sipil untuk Transformasi Sosial, Pustaka Pelajar, 1966.

Gafar, Afan, Politik Indonesia: Transisi Menuju Demokrasi, Pustaka Pelajar, 1999.

Held, David, Models of Democracy (terj), The Akbar Tandjung Institute, Jakarta, 2006.

Huntington, Samue P., Gelombang Demokratisasi Ketiga, Pustaka Utama Grafiti, Jakarta, 2001.

Lin, Nan,SocialMovementdalam Encyclopedia of Sociology, New York: MacMillan Publishing Company, 1992.

McDonald, Cameron Lee, Western Political Theory, Jilid II, Harcourt Brace Javanovich, New York, 1968.

Sanit, Arbi, Reformasi Politik, Yogyakarta, Pustaka Pelajar, 1998.

Sanit, Arbi, Sistim Politik Indonesia, Jakarta, Penerbit CV Rajawali, 1981.

Varma, SP., Teori Politik Modern, PT. Raja Grafindo Persada, 2007

JA, Denny, Menjelaskan Gerakan Mahasiswa, Harian Kompas, 25 April 1998, diambil dari www.kompas.com, tanggal 5 Mei 2010, jam 14.00 wib.

Nasir Siregar, Ahmad, Mahasiswa dan Perubahan Sosial (makalah), http:// hmi.or.id/berita/44/mahasiswa-danperubahan-sosial, diunduh tanggal 5 Mei 2010, jam 11.00 wib 